\title{
Antioxidant effect of dehydrated rosemary leaves in ripened semi-hard cheese: A study using coupled TG-DSC-FTIR (EGA)
}

\author{
Marina Tolentino Marinho a, b, Luciano dos Santos Bersot ${ }^{\mathrm{a}}$, Alessandro Nogueira ${ }^{\mathrm{b}}$, \\ Tiago André Denck Colman ${ }^{\mathrm{b}, \mathrm{c}}$, Egon Schnitzler ${ }^{\mathrm{b}, *}$ \\ ${ }^{a}$ Federal University of Paraná, R. Cel. Francisco H. dos Santos, s/n, 81531-980, Curitiba, PR, Brazil \\ b State University of Ponta Grossa, Av. Carlos Cavalcanti, 4748, 84030-900, Ponta Grossa, PR, Brazil \\ c São Paulo State University - Chemistry Institute, R. Prof. Francisco Degni, 55, 14800-060, Araraquara, SP, Brazil
}

\section{A R T I C L E I N F O}

\section{Article history:}

Received 16 December 2014

Received in revised form

17 March 2015

Accepted 30 March 2015

Available online 17 April 2015

\section{Keywords:}

Thermal analysis

FTIR

Enthalpy

Kinetic study

\begin{abstract}
A B S T R A C T
The Evolved Gas Analysis (EGA) is a group of techniques (in this case coupled TG-DSC and FTIR) that can provide information regarding mass changes, exothermal and endothermal events, as well as gaseous products that are evolved during events. In this study, semi-hard cheeses were manufactured and the lipid fractions were assessed by the above-mentioned techniques and others such GC/MS and ${ }^{1} \mathrm{H}$ NMR, and kinetic parameters were calculated using thermogravimetry. The samples were divided into three portions: (a) cheeses $24 \mathrm{~h}$ after manufacture; (b) cheeses after 60 days of ripening; (c) cheeses covered with lard and rosemary after 60 days of ripening. It was observed that the fat from samples treated with rosemary leaves showed higher decomposition temperatures (TG), higher resistance to the oxidation process $\left(\mathrm{T}_{\mathrm{p}}=310.2{ }^{\circ} \mathrm{C}\right)$ and enthalpy $\left(1228.5 \mathrm{~J} \mathrm{~g}^{-1}\right)$. The FTIR spectroscopy of the gaseous products of decomposition obtained simultaneously with TG-DSC curves revealed that the main bands could be attributed to $-\mathrm{C}-\mathrm{H},-\mathrm{COOH}$ stretching with the formation of $\mathrm{CO}, \mathrm{CO}_{2}$ and tetradecanoicacid-7-oxomethylester compounds. An increase in the value of the activation energy in cheese covered with rosemary leaves was associated with antioxidant activity.
\end{abstract}

(c) 2015 Elsevier Ltd. All rights reserved.

\section{Introduction}

Lipids (oils and fats) are unstable substances and they may exhibit auto-oxidation, which is an irreversible process leading to rancidity and a reduction in flavour and nutritive value. The lipid oxidation is the major cause of deterioration during the shelf-life of foods (Basaga, Tekkaya, \& Acikel, 1987; Casarotti \& Jorge, 2014; Georgantelis, Blekas, Katikou, Ambrosiadis, \& Fletouris, 2007).

In order to retard, reduce and/or prevent oxidative deterioration in foods, as well as the alterations of sensory properties of foods some antioxidants can be added. The main synthetic substances used for these purposes are: butylated hydroxy anisole (BHA), butylated hydroxy toluene (BHT), propyl-galate (PG) and tert-butil hydroxyl quinone (TBHQ) (Frutos \& Hernández-Herrero, 2005; Kulisik, Radonic, Katalinik, \& Milos, 2004). However, the literature reports that these substances have been suspected of causing or promoting negative health effects (Karpinska, Borowski, \&

\footnotetext{
* Corresponding author.

E-mail address: egons@uepg.br (E. Schnitzler).
}

Danowski-Oziewicz, 2001; Kulisik et al., 2004; Peiretti, Gai, Ortoffi, Aigotti, \& Medana, 2012) and consequently, consumers have shown a growing tendency to reject many synthetic additives in foods, which are mainly synthetic antioxidants (Gamel \& Kiritsakis, 1999).

The antioxidant capacity of rosemary spice (as oil, extracts or leaves) is associated with the presence of phenolic compounds, such as carnosic acid, rosmarinic acid, carnosol, rosmanol, rosmariquinone and rosmaridiphenol, which react with the free radicals formed during the oxidation process (Aruoma, Halliwell, Aeschbach, \& Löliger, 1992) and break the chain reaction by donating electrons (Georgantelis et al., 2007).

The main properties described in the literature and attributed to rosemary spice as oil, an extract, or even the leaves are: antibacterial (Dragoni \& Vallone, 2009), antifungal (Dragoni \& Vallone, 2009; Rasooli et al., 2008), antimicrobial (Moreira, Ponce, Del Valle, \& Roura, 2005; Ponce, Roura, \& Moreira, 2011), biopreservative (Ponce et al., 2011), insecticide (Dragoni \& Vallone, 2009), metal chelating additive (Basaga et al., 1987) and antioxidant (Basaga et al., 1987; Casarotti \& Jorge, 2014; Martínez, Penci, 
Ixatina, Ribotta, \& Maestri, 2013; Moreira et al., 2005; Olmedo, Nepote, \& Grosso, 2013; Peiretti et al., 2012).

Thus, the aim of this study was to investigate the thermal behaviour of samples from the lipid fraction obtained from semihard cheeses made with raw milk covered (and not covered) with lard and rosemary leaves. This investigation was carried out to assess the antioxidative effect of rosemary leaves under the following conditions: (a) fat from uncoated cheese extracted $24 \mathrm{~h}$ (one day) after manufacture, (b) fat from uncoated cheese extracted $1440 \mathrm{~h}$ (60 days) after manufacture and (c) fat from cheese covered with lard and rosemary leaves and extracted 1440 h (60 days) after manufacture.

The GC/MS and ${ }^{1} \mathrm{H}$ NMR techniques were used for determination of fatty acids composition and structural modifications of fats. The thermal analysis (TG, DSC, EGA) were performed for determine the gases produced during thermal decomposition and made kinetic studies, for evaluate the antioxidant activity of rosemary.

\section{Materials and methods}

Samples were taken from two batches of cheese produced at the dairy pilot plant at the Technological School of Milk and Cheese of Campos Gerais (ETLQueijos-UEPG) at the State University of Ponta Grossa (UEPG), Paraná, Brazil. The protocol consisted of the use of $75 \mathrm{~L}$ (each batch) of raw milk from Holstein cows. The manufacturing process started with the addition of commercial lyophilised direct-to-vat thermophilic starter culture (Biolact T-12) containing Streptococcus thermophilus, Lactobacillus helveticus, Lactobacillus delbrueckii spp. bulgaricus and Lactobacillus casei. Twenty min after the inoculation of the culture, $0.4 \mathrm{~mL} \mathrm{~L}^{-1}$ of a solution at $5 \times 10^{2} \mathrm{~g} \mathrm{~L}^{-1}$ of calcium chloride and $0.016 \mathrm{~g} \mathrm{~L}^{-1}$ rennet powder (HA-LA 2154 IMCU, Chr. Hansen) were added. After coagulation, the curd was cut with the aid of curd cutters into $1 \mathrm{~cm}$ edged cubes, followed by continuous and slow stirring of the mass for $20 \mathrm{~min}$. This was followed by partial syneresis (removing $0.3 \mathrm{~L} \mathrm{~L}^{-1}$ of the whey), a second agitation and the addition of $0.2 \mathrm{~L} \mathrm{~L} \mathrm{~L}^{-1}$ water at $70-80{ }^{\circ} \mathrm{C}$. After 60 min the mass was precompressed (twice the weight of the mass) for $15 \mathrm{~min}$, transferred to polypropylene moulds ( $110 \mathrm{~mm}$ diameter by $86 \mathrm{~mm}$ height), and subjected to pressing with the same mass weight for $90 \mathrm{~min}$ and turning every $30 \mathrm{~min}$. When the pressing time was reached, the cheeses were removed from the moulds, placed in brine at $160 \mathrm{~g} \mathrm{~L}^{-1}$ for $24 \mathrm{~h}$. Subsequently, the samples were taken to the maturation chamber with a controlled temperature of $12 \pm 2{ }^{\circ} \mathrm{C}$ and a relative humidity of $85-90 \%$. From each batch 16 pieces of cheese of about $400 \mathrm{~g}$ were obtained.

On the fifteenth day of maturation (ripening), half the cheeses were covered with a layer of lard in a proportion of $30 \mathrm{~g} \mathrm{~kg}^{-1}$ and dehydrated rosemary leaves at a ratio of $40 \mathrm{~g} \mathrm{~kg}^{-1}$ and were maintained for 45 more days, (i.e., 60 days of ripening). The uncoated cheeses were also ripened for 60 days.

One piece of cheese from each batch was removed from the maturation chamber for the extraction of fat on each of the designated dates - $24 \mathrm{~h}$ of ripening (one day), which was called sample (a); after $1440 \mathrm{~h}$ (60 days) of ripening, the uncoated cheeses, which were called sample (b); and after $1440 \mathrm{~h}$ (60 days) of ripening, the cheeses covered with $30 \mathrm{~g} \mathrm{~kg}^{-1}$ lard and $40 \mathrm{~g} \mathrm{~kg}^{-1}$ rosemary leaves, which were called sample (c). The cheeses coated with rosemary were scraped to remove the rosemary and fat before analysis.

The procedure for fat extraction was in accordance with that described by Taracki, Temiz, Aykut, and Turhan (2011) and was as follows: up to $10 \mathrm{~g}$ of ground sample was added to $60 \mathrm{~mL}$ of chloroform:ethanol (2:1 mL:mL), which was stirred using an Ultra Turrax homogeniser for $3 \mathrm{~min}$. Then $15 \mathrm{~mL}$ of $1 \times 10^{-3} \mathrm{Mol} \mathrm{L}^{-1}$ solution of calcium chloride was added, followed by vigorous stirring for $30 \mathrm{~s}$. The mixture was centrifuged $(2000 \times g)$ for around $15 \mathrm{~min}$. The phases were then separated and evaporated to chloroform phase in a rotary evaporator under reduced pressure at $40{ }^{\circ} \mathrm{C}$.

\subsection{Thermogravimetry and differential scanning calorimetry (TG-DSC)}

The simultaneous TG-DSC curves were obtained by using a Mettler Toledo TGA-DSC 1 star $^{\mathrm{e}}$ system. The purge gas was an air flow of $50 \mathrm{~mL} \mathrm{~min}{ }^{-1}$ and a heating rate of $10^{\circ} \mathrm{C} \mathrm{min}^{-1}$ was adopted, with samples weighing about $20 \mathrm{mg}$. Alumina crucibles were used to record the TG-DSC curves. The DSC curves permitted the determination of the thermal events, such as exotherm or endotherm reactions, as well as making it possible to determine the main oxidation temperatures and to calculate the enthalpy $(\Delta \mathrm{H})$.

\subsection{Evolved gas analysis (EGA)}

The measurements of the gaseous products were carried by using a Nicolet FT-IR spectrophotometer with gas cell and DTGS KBr detector coupled to a Mettler Toledo TG-DSC. The furnace and the heated gas cell $\left(250{ }^{\circ} \mathrm{C}\right)$ were coupled through a heated $\left(225^{\circ} \mathrm{C}\right)$ $120 \mathrm{~cm}$ stainless steel line transfer with diameter of $3 \mathrm{~mm}$, both purged with dry air $\left(50 \mathrm{~mL} \mathrm{~min}^{-1}\right)$. The FTIR spectra were recorded with 16 scans per spectrum at a resolution of $4 \mathrm{~cm}^{-1}$. The FTIR spectra of the decomposition gases were analysed using the OMINIC ThermoScientific v. 8.0 software programme.

\subsection{Differential scanning calorimetry (DSC)}

The Differential Scanning Calorimetry (DSC) curves were obtained using DSC-Q200 (TA Instruments, USA) equipment. The instrument was previously calibrated using Indium 99.99\% purity, m.p. $=156.6^{\circ} \mathrm{C}, \Delta H=28.56 \mathrm{~J} \mathrm{~g}^{-1}$ The samples were heated from $30^{\circ} \mathrm{C}$ to $600{ }^{\circ} \mathrm{C}$ using an aluminum crucible with a pierced lid with a $1.0 \mathrm{~mm}$ diameter orifice and approximately $4 \mathrm{mg}$ of each sample under an air flow rate of $150 \mathrm{~mL} \mathrm{~min}^{-1}$ at a heating rate of $10{ }^{\circ} \mathrm{C} \mathrm{min}^{-1}$.

\subsection{GC/MS analysis}

The triacylglycerol (fat cheese) samples were initially submitted to a transesterification procedure in order to convert the triacylglycerol into fatty acid methyl esters. The determinations of fatty acid composition by GC/MS were performed on a Varian Saturn 2000R instrument equipped with an Agilent DB-225-MS capillary column. The GC conditions were as follows: initial temperature, $50{ }^{\circ} \mathrm{C}$; final temperature, $210{ }^{\circ} \mathrm{C}$; heating rate, $40{ }^{\circ} \mathrm{C} \mathrm{min}{ }^{-1}$. Carrier gas, helium, at the flow rate of $1.0 \mathrm{~mL} \mathrm{~min}{ }^{-1}$.

In order to make it possible to determine the fatty acid composition by means of GC analysis, initially the retention times were determined by injecting a standard solution containing a mixture of fatty acid methyl esters.

\subsection{Kinetic study}

The kinetic study of the oxidation process was based on Ozawa's non-isothermal method and was applied to the thermogravimetric (TG) curves. The results obtained using the thermal analysis system TGA-50 (Shimadzu, Japan) were under the following conditions: $4 \mathrm{mg}$ of sample were used in an open alumina crucible in an air flow of $150 \mathrm{~mL} \mathrm{~min}{ }^{-1}$; the samples were heated from $30{ }^{\circ} \mathrm{C}$ to $600{ }^{\circ} \mathrm{C}$ at heating rates of $10,15,20,25$ and $30{ }^{\circ} \mathrm{C} \mathrm{min}{ }^{-1}$. The instrument was 
first calibrated with standard weight and calcium oxalate monohydrate. ${ }^{1} \mathrm{H}$ NMR.

The NMR analyzes were performed on a Bruker 400 NMR spectrometer operating a $9.4 \mathrm{~T}$ observing the ${ }^{1} \mathrm{H}$ nuclei at $400.13 \mathrm{MHz}$. For this, aliquots of approximately $10 \mu \mathrm{l}$ of each sample were directly transferred into $5-\mathrm{mm}$ NMR tubes and the volume was completed to $500 \mu \mathrm{l}$ with $\mathrm{CDCl}_{3}$ containing $5 \times 10^{-3} \mathrm{~g} \mathrm{~L}^{-1} \mathrm{TMS}$. The ${ }^{1} \mathrm{H}$ NMR spectra were recorded at $30^{\circ} \mathrm{C}$. by accumulating thirty two scans, a relaxation delay of $1 \mathrm{~s}$, spectral width of $\sim=9.1 \mathrm{ppm}$ and $64 \mathrm{~K}$ data points. The ${ }^{1} \mathrm{H}$ NMR chemical shifts are expressed in ppm related to the TMS signal at $0.00 \mathrm{ppm}$ as internal reference.

\section{Results and discussion}

The TG-DSC curves of the fat from the cheeses (Fig. 1) showed three steps of mass loss. It is suggested that the first step was associated with the loss of low residual solvent used in the extraction of the samples, which in the DSC curves was observed as a large endotherm phenomenom, with mass loss of 3.92, 2.73 and $1.21 \%$ of initial mass. The second step was due to the decomposition of monounsaturated and polyunsaturated fatty acids, and the third step was due to the decomposition of saturated fatty acids, which in the DSC curves were observed as two exothermic peaks.

The main values related to the simultaneous TG-DSC curves are gathered together in Table 1: The DSC curves are depicted in Fig. 2 and showed similar behaviour to the TG-DSC curves. There were

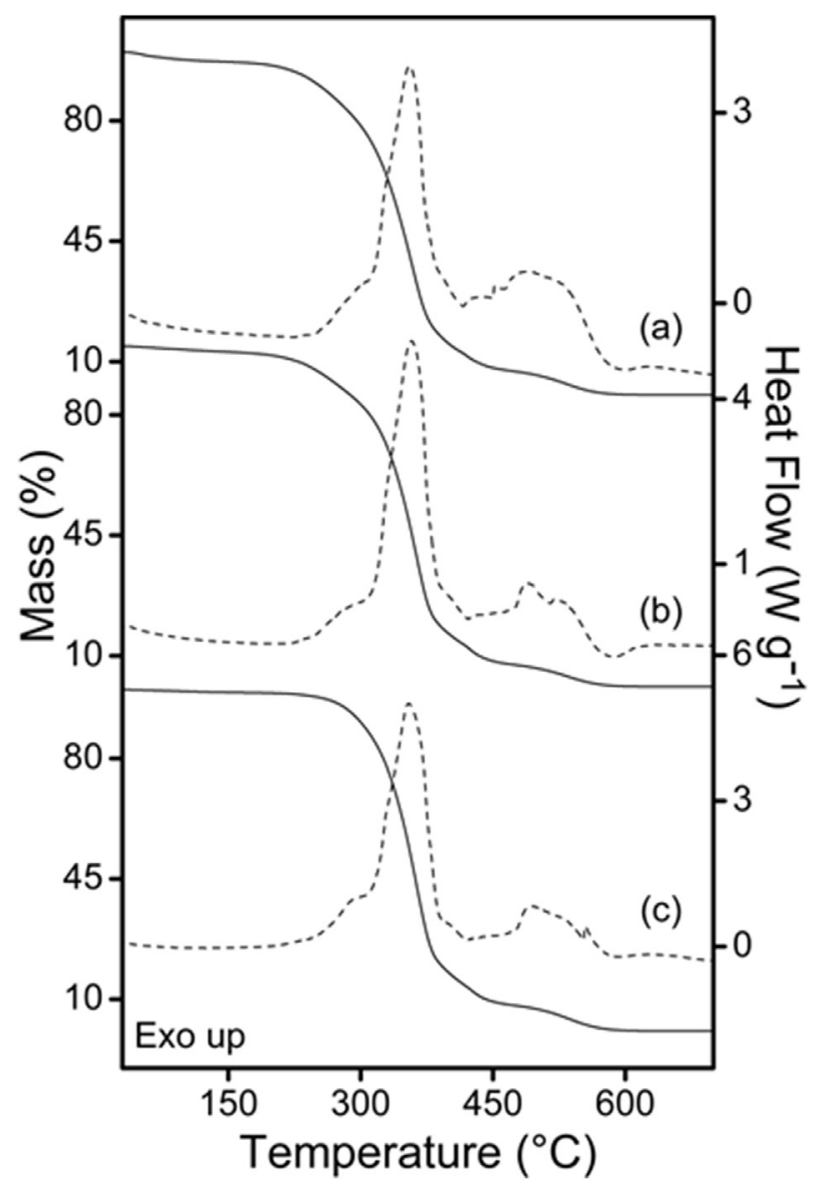

Fig. 1. Simultaneous TG-DSC curves of fat extracted from semi-hard cheese: (a) fat from uncoated cheese extracted after $24 \mathrm{~h}$ (one day) of manufacture, (b) fat from uncoated cheese extracted after $1440 \mathrm{~h}$ (60 days) of ripening and (c) fat from cheese covered with lard and rosemary leaves extracted after $1440 \mathrm{~h}$ (60 days) of ripening. TG - solid line, DSC - dash line.
Table 1

Main results obtained for each step of TG-DSC curves: (a) 24 h of ripening; (b) uncoated $-1440 \mathrm{~h}$ of ripening; (c) coated $-1440 \mathrm{~h}$ of ripening.

\begin{tabular}{llllll}
\hline \multicolumn{2}{l}{ Samples } & 1st Step & 2nd Step & 3rd Step & Ash \\
\hline (a) & $\theta\left({ }^{\circ} \mathrm{C}\right)$ & $30-199$ & $199-414$ & $414-585$ & - \\
& $\mathrm{T}_{\mathrm{p}}\left({ }^{\circ} \mathrm{C}\right)$ & - & 355 exo & 490 exo & - \\
& $\Delta \mathrm{m}(\%)$ & 3.92 & 83.39 & 12.50 & 0.19 \\
(b) & $\theta\left({ }^{\circ} \mathrm{C}\right)$ & $30-200$ & $200-420$ & $420-584$ & - \\
& $\mathrm{T}_{\mathrm{p}}\left({ }^{\circ} \mathrm{C}\right)$ & - & $356 \mathrm{exo}$ & $488 \mathrm{exo} ; 520 \mathrm{exo}$ & - \\
& $\Delta \mathrm{m}(\%)$ & 2.73 & 84.90 & 12.27 & 0.10 \\
(c) & $\theta\left({ }^{\circ} \mathrm{C}\right)$ & $30-220$ & $220-422$ & $422-595$ & - \\
& $\mathrm{T}_{\mathrm{p}}\left({ }^{\circ} \mathrm{C}\right)$ & - & $356 \mathrm{exo}$ & $490 \mathrm{exo} ; 555 \mathrm{exo}$ & - \\
& $\Delta \mathrm{m}(\%)$ & 1.21 & 85.36 & 13.30 & 0.13 \\
\hline
\end{tabular}

$\theta=$ temperature range; $\mathrm{T}_{\mathrm{p}}=$ peak temperature; $\Delta \mathrm{m}=$ mass loss.

two major exothermic peaks for all the samples; the first peak with $\mathrm{T}_{\mathrm{p}}$ at 299,305 and $319{ }^{\circ} \mathrm{C}$, respectively, and the second with $\mathrm{T}_{\mathrm{p}}$ at 512,511 and $511^{\circ} \mathrm{C}$, respectively.

The curves followed the model of the autocatalytic reaction of lipids by free radicals. Initially, peroxide formation occurred and the second peak resulted from the decomposition of peroxides into secondary oxidation products (Ixtaina, Nolasco, \& Tomás, 2012).

In agreement with the literature (Polavka, Paligová, Cvengros, \& Simon, 2005), the polymerisation of monomers formed during the decomposition of polyunsaturated fatty acids was an endothermic step and the oxidative decomposition of unsaturated and saturated fatty acids referred to an exothermic event.

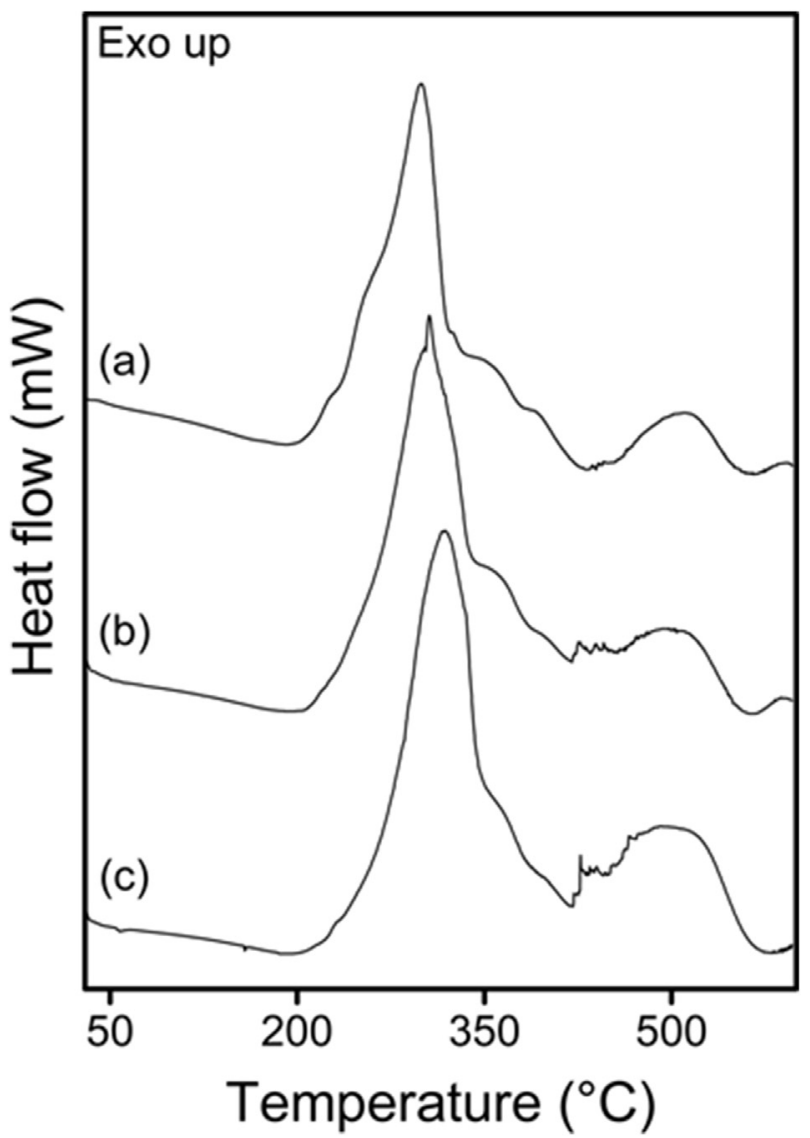

Fig. 2. DSC curves of fat extracted from semi-hard cheese: (a) fat from uncoated cheese extracted after $24 \mathrm{~h}$ (one day) of manufacture, (b) fat from uncoated cheese extracted after $1440 \mathrm{~h}$ (60 days) of ripening and (c) fat from cheese covered with lard and rosemary leaves extracted after $1440 \mathrm{~h}$ (60 days) of ripening. 
Table 2

Results of DSC analysis: (a) $24 \mathrm{~h}$ of ripening; (b) uncoated $-1440 \mathrm{~h}$ of ripening; (c) coated $-1440 \mathrm{~h}$ of ripening.

\begin{tabular}{|c|c|c|c|c|c|c|c|c|}
\hline \multirow[t]{2}{*}{ Samples } & \multicolumn{4}{|l|}{ 1st Peak } & \multicolumn{4}{|l|}{ 2nd Peak } \\
\hline & $\mathrm{T}_{\mathrm{o}}\left({ }^{\circ} \mathrm{C}\right)$ & $\mathrm{T}_{\mathrm{p}}\left({ }^{\circ} \mathrm{C}\right)$ & Tc $\left({ }^{\circ} \mathrm{C}\right)$ & $\Delta \mathrm{H}\left(\mathrm{J} \mathrm{g}^{-1}\right)$ & $\mathrm{T}_{\mathrm{o}}\left({ }^{\circ} \mathrm{C}\right)$ & $\mathrm{T}_{\mathrm{p}}\left({ }^{\circ} \mathrm{C}\right)$ & Tc $\left({ }^{\circ} \mathrm{C}\right)$ & $\Delta \mathrm{H}\left(\mathrm{J} \mathrm{g}^{-1}\right)$ \\
\hline (a) & $250.84 \pm 0.51^{b}$ & $304.50 \pm 0.71^{b}$ & $320.63 \pm 4.76^{a}$ & $1149.00 \pm 48.10^{b}$ & - & - & - & - \\
\hline (b) & $251.20 \pm 0.44^{\mathrm{b}}$ & $301.07 \pm 1.55^{\mathrm{c}}$ & $331.08 \pm 6.47^{a}$ & $1161.50 \pm 38.90^{\mathrm{b}}$ & $439.80 \pm 23.70^{\mathrm{a}}$ & $512.56 \pm 10.08^{a}$ & $552.99 \pm 5.36^{\mathrm{a}}$ & 305.90 \\
\hline (c) & $269.32 \pm 0.22^{\mathrm{a}}$ & $310.20 \pm 1.40^{\mathrm{a}}$ & $322.56 \pm 9.61^{\mathrm{a}}$ & $1228.50 \pm 19.10^{a}$ & $424.64 \pm 9.10^{a}$ & $509.29 \pm 2.35^{\mathrm{a}}$ & $547.86 \pm 16.33^{\mathrm{a}}$ & 450.40 \\
\hline
\end{tabular}

“ $\mathrm{T}_{\mathrm{o}}$ " Onset temperature, " $\mathrm{T}_{\mathrm{p}}$ " Peak temperature, " $\mathrm{T}_{\mathrm{c}}$ " Conclusion temperature, " $\Delta \mathrm{H}$ " Enthalpy.

${ }^{a b c}$ Different letters in the same column indicate significant statistical differences between cheeses (Tukey Test, $\mathrm{p}<0.05$ ).

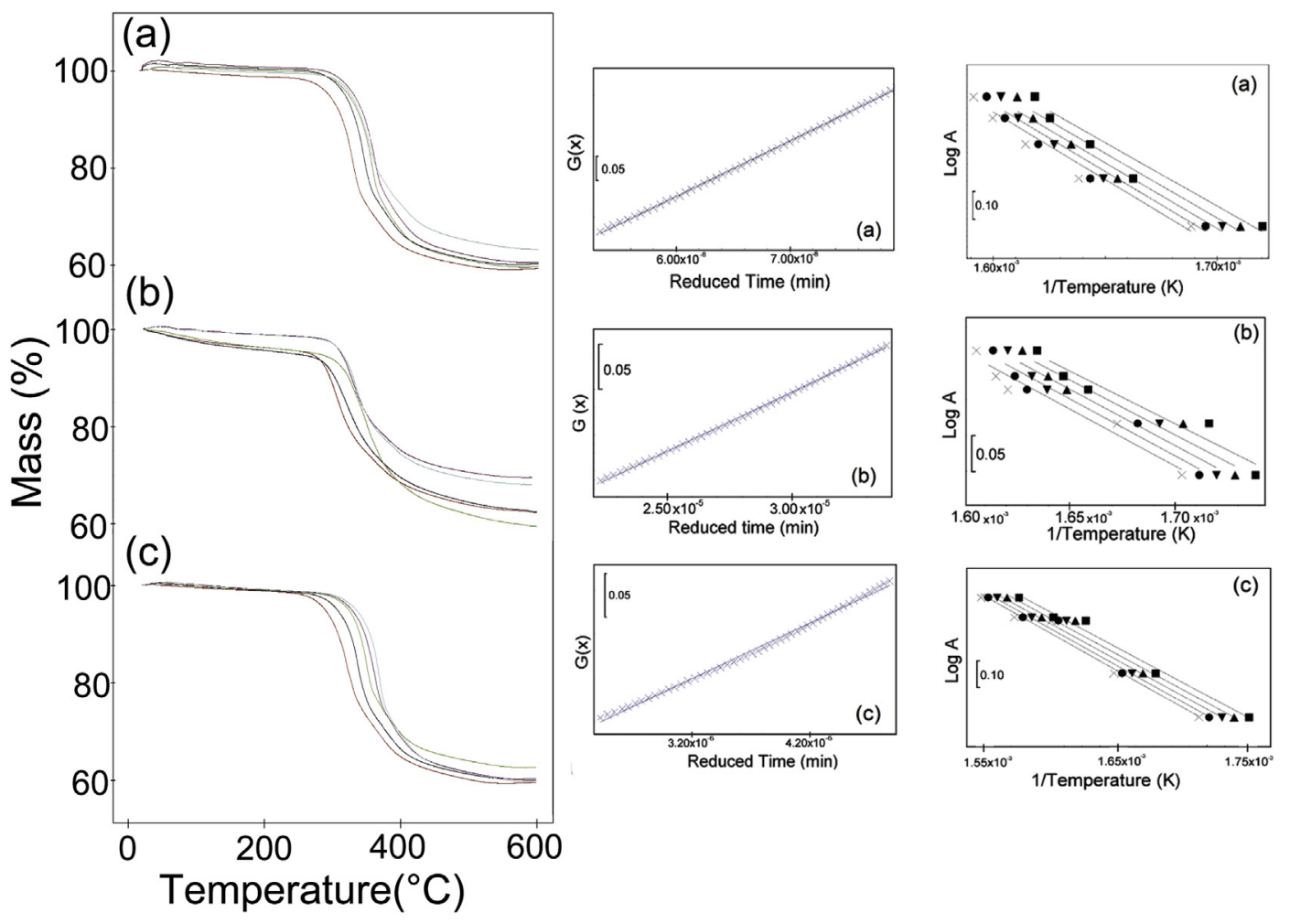

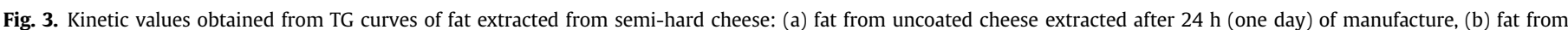
uncoated cheese extracted after 1440 h (60 days) of ripening and (c) fat from cheese covered with lard and rosemary leaves extracted after 1440 h (60 days) of ripening.

The GC/MS results (supplementary materials) showed that fat cheeses contained predominantly monounsaturated and saturated fatty acids. No endothermic events were observed in the DSC curves obtained in this study. Szabo, Chambre, and Iditoiu (2012) observed the same trend in swine fat.

The results obtained from the DSC curves are shown in Table 2. The onset temperature $\left(T_{0}\right)$, peak temperature $\left(T_{p}\right)$ and endset or conclusion temperature $\left(\mathrm{T}_{\mathrm{c}}\right)$, as well as enthalpy, were calculated.

Many factors influence the activation energy required to promote enthalpic events, such as the presence of antioxidants and the relationship between saturated and unsaturated fatty acids (Simon, Kolman, Niklova, \& Schmidt, 2000).

The thermal decomposition of unsaturated fatty acids requires less energy than the decomposition of saturated fatty acids (Kasprzycha-Guttman \& Cozeniak, 1991). Using the study of the oxidation kinetics (Fig. 3 ) it was possible to determine the activation energy of the event by calculating the first $10 \%$ of mass loss associated with the oxidation of the samples.

According to Kovalski, Ratusz, Miciula, and Krygier (1997), the thermal oxidation of lipids is an exothermic reaction that can be measured by enthalpy variations. In the present study the fat extracted from the cheese covered with rosemary leaves showed higher oxidation temperatures $\left(T_{o}\right.$ and $T_{p}$ ) as well as higher enthalpy values $(\Delta \mathrm{H})$. The ${ }^{1} \mathrm{H}$ RMN results (supplementary materials) show that no structural modifications, suggesting that the antioxidant activity occurs due rosemary presence, demonstrated when the fat is subjected to thermal stress.

The antioxidant activity of rosemary is attributed to the presence of phenolic diterpenes, such as carnosol and carnosic acid, as well as its capacity to donate electrons to free radicals and terminate the chain reaction (Madsen \& Bertelsen, 1995).

The results obtained from the kinetic study of the oxidation of the samples using the Flynn-Wall-Ozawa non-isothermal method are shown in Table 3.

Table 3

Kinetic parameters obtained of oxidation: (a) $24 \mathrm{~h}$ of ripening; (b) uncoated $1440 \mathrm{~h}$ of ripening; (c) coated $-1440 \mathrm{~h}$ of ripening.

\begin{tabular}{llll}
\hline Samples & $\mathrm{E}_{\mathrm{a}}\left(\mathrm{kJ} \mathrm{mol}^{-1}\right)$ & Reaction order & Arrhenius frequency factor \\
\hline (a) & $56.15 \pm 1.73$ & $1 \mathrm{st}$ & $1.30 \times 10^{-4}$ \\
(b) & $59.05 \pm 1.48$ & $1 \mathrm{st}$ & $6.34 \times 10^{-4}$ \\
(c) & $85.91 \pm 2.07$ & $1 \mathrm{st}$ & $3.88 \times 10^{-6}$ \\
\hline
\end{tabular}

$\mathrm{E}_{\mathrm{a}}=$ activation energy. 


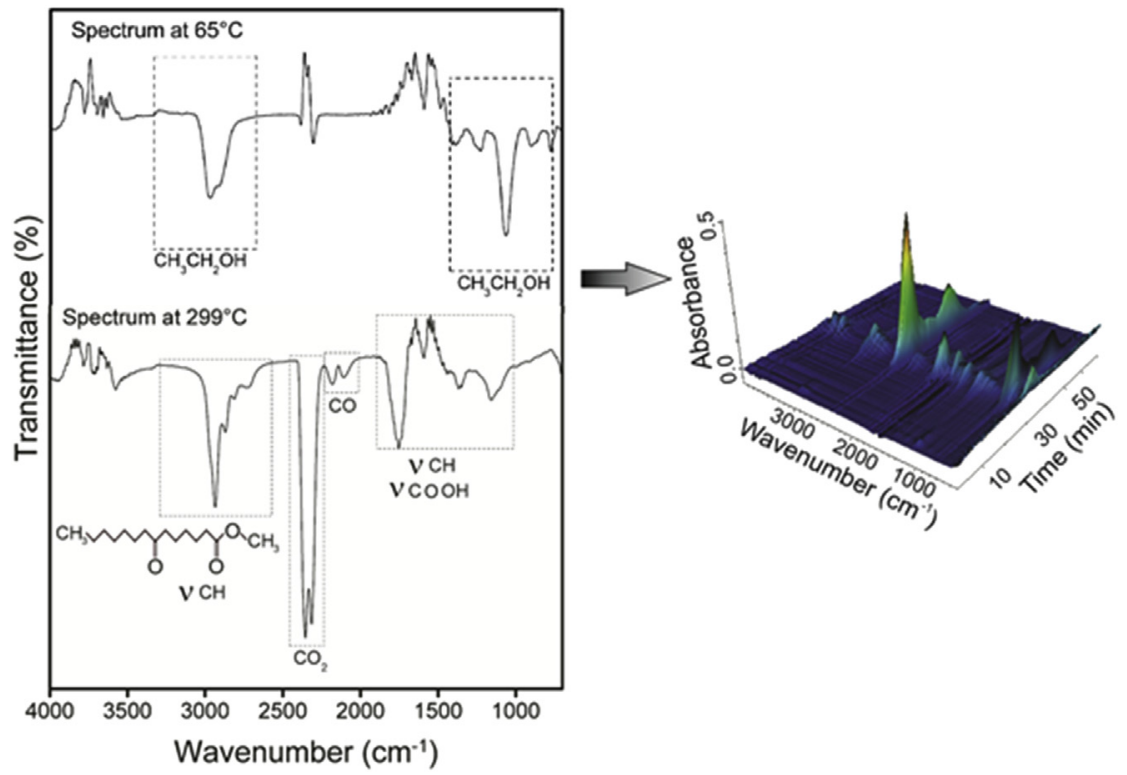

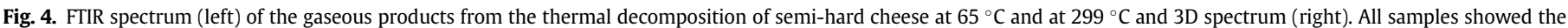
same products of thermal decomposition.

The results regarding activation energy, in agreement with this method (Flynn-Wall-Ozawa), were in accordance with the enthalpy values, namely that sample (c) showed higher $\mathrm{E}_{\mathrm{a}}$ and $\Delta \mathrm{H}$ oxidation values, suggesting that the cheeses covered with rosemary had a higher resistance to the oxidation process. The FTIR spectrum of the decomposition gases are given in Fig. 4.

With regards to the FTIR spectrum, all thethe the studied samples showed similar behaviour. This technique suggests by comparing experimental spectrum and those of the library in OMINIC from "Thermo Fischer Scientific Inc., USA, Software OMNIC 8.0.342." software, which the release of ethanol in the first stage of decomposition and in a second stage was observed the release from a mixture of gases that have bands that can be assigned to $-\mathrm{C}-\mathrm{H}$, $-\mathrm{COOH}$ stretching in agreement with literature (Silverstein, Bassler, \& Morrill, 2005) as well as compounds $\mathrm{C}_{15} \mathrm{H}_{28} \mathrm{O}_{3}$ (Tetradecanoicacid-7-oxo-methylester), as well as the main bands from $\mathrm{CO}$ and $\mathrm{CO}_{2}$.

\section{Conclusion}

In this study the samples covered with rosemary leaves showed an increase in the stability of the lipid fraction when compared with early maturation cheeses or uncoated cheeses. The lipid fraction of the coated cheeses showed greater stability, with higher degradation and oxidation temperatures when the thermo-oxidative process was accelerated. The sample containing rosemary had an average increase of $53 \%$ in the value of the activation energy associated with the oxidation of the samples.

FTIR showed the release of the gases in the first two steps, which were release residues of the solvent used in the extraction of the samples $\left(\mathrm{CH}_{3} \mathrm{CH}_{2} \mathrm{OH}\right)$, and in the second stage a gas mixture was observed more effective form $\mathrm{CO}_{2}$ and $\mathrm{CO}$, which was attributed to $\mathrm{CH}$ and $\mathrm{COOH}$ stretching.

\section{Conflict of interest statement}

The authors declare that there are no conflicts of interest.

\section{Acknowledgements}

The authors are grateful to Prof. Dr. Andersson Barison for the ${ }^{1} \mathrm{H}$ NMR spectra, Prof. Dr. Massao Ionashiro for the EGA analysis, CAPES, FAPESP, CNPq for the financial support.

\section{Appendix A. Supplementary data}

Supplementary data related to this article can be found at http:// dx.doi.org/10.1016/j.lwt.2015.03.108.

\section{References}

Aruoma, O. I., Halliwell, B., Aeschbach, R., \& Löliger, J. (1992). Antioxidant and prooxidant properties of active rosemary constituents: carnosol and carnosic acid. Xenobiotica, 22, 257-268.

Basaga, H., Tekkaya, C., \& Acikel, F. (1987). Antioxidative and free radical scavenging properties of rosemary extract. LWT-Food Science and Technology, 30, 105-108.

Casarotti, S. N., \& Jorge, N. (2014). Antioxidant activity of rosemary extract in soybean oil under thermooxidation. Journal of Food Processing and Preservation, 38, $136-145$.

Dragoni, I., \& Vallone, L. (2009). Antifungal activity of rosemary essential oil against foodstuffs fungi. Italian Journal of Food Safety, 4, 17-20.

Frutos, M. J., \& Hernández-Herrero, J. A. (2005). Effects of Rosemary extract (Rosmarinus officinalis) on the stability of bread with anoil, garlic and parsley dressing. LWT-Food Science and Technology, 38, 651-655.

Gamel, T. H., \& Kiritsakis, A. (1999). Effect of methanol extracts of rosemary and olive vegetable water on the stability of olive oil and sunflower oil. Grasas $y$ Aceites, 5, 345-350.

Georgantelis, D., Blekas, G., Katikou, P., Ambrosiadis, I., \& Fletouris, D. J. (2007) Effect of rosemary extract, chitosan and $\alpha$-tocopherol on lipid oxidation and colour stability during frozen storage of beef burgers. Meat Science, 75, 256-264.

Ixtaina, V. Y., Nolasco, S. M., \& Tomás, M. C. (2012). Oxidative stability of Salvia hispanica seed oil: effect of antioxidants and storage Condition. Journal of the American Oil Chemists' Society, 89, 1077-1090.

Karpinska, M., Borowski, J., \& Danowski-Oziewicz, M. (2001). The use of natural antioxidants in ready-to-serve food. Food Chemistry, 72, 5-9.

Kasprzycha-Guttman, T., \& Cozeniak, D. (1991). Specific heat of some pharmaceutical oils and fats measured by differential scanning calorimetry at $70-140^{\circ} \mathrm{C}$. Thermochimica Acta, 191, 41-45.

Kovalski, B., Ratusz, K., Miciula, A., \& Krygier, K. (1997). Monitoring of rapeseed oil autoxidation with a pressure differential scanning calorimeter. Thermochimica Acta, 307, 117-121. 
Kulisik, T., Radonic, A., Katalinik, V., \& Milos, M. (2004). Use of different methods for testing antioxidative activity of oregano essential oil. Food Chemistry, 85, 633-640.

Madsen, H. L., \& Bertelsen, G. (1995). Spices as antioxidants. Trends in Food Science and Technology, 6, 271-277.

Martínez, M. L., Penci, M. C., Ixatina, V., Ribotta, P. D., \& Maestri, D. (2013). Effect of natural and syntethic antioxidants on the oxidative stability of walnut oil under different storage conditions. LWT-Food Science and Technology, 51, 44-50.

Moreira, M. R., Ponce, A. G., Del Valle, C. E., \& Roura, S. I. (2005). Inhibitory parameters of essential oils to reduce a food borne pathogen. LWT-Food Science and Technology, 38, 565-570.

Olmedo, R. H., Nepote, V., \& Grosso, N. R. (2013). Preservation of sensory and chemical properties in flavoured cheese prepared with cream cheese base using oregano and rosemary essential oils. LWT-Food Science and Technology, 53, 409-417.

Peiretti, P. G., Gai, F. Ortoffi, M., Aigotti, R. \& Medana, C. (2012). Effects of rosemary oil (Rosmarinus officinalis) on the shelf-life of minced rainbow trout (Oncorhynchus mykiss) during refrigerated storage. Foods, 1, 28-39.

Polavka, J., Paligová, J., Cvengros, J., \& Simon, P. (2005). Oxidation stability of methyl esters studied by differential thermal analysis and rancimat. Journal of American Oil Chemists Society, 82, 519-524.
Ponce, A., Roura, S. I., \& Moreira, M. R. (2011). Essential oils as biopreservatives: different methods for the technological application in lettuce leaves. Journal of Food Science, 76, 34-40.

Rasooli, I., Fakoor, M. H., Yadegarinia, D., Gachkar, L., Allmeh, A., \& Razaei, M. B. (2008). Antimycotoxigenic characteristics of Rosmarius officinallis and Trachyspermumcopticum L. essential oils. International Journal of Food Microbiology, $122,135-139$.

Silverstein, R. M., Bassler, G. C., \& Morrill, T. C. (2005). Spectrometric identification of organic compounds (7th ed.). New York: John Wiley \& Sons.

Simon, P., Kolman, L., Niklova, I., \& Schmidt, S. (2000). Analysis of the induction period of oxidation of edible oils by differential scanning calorimetry. Journal of American Oil Chemists Society, 77, 639-642.

Szabo, M. R., Chambre, D., \& Iditoiu, C. (2012). TG/DTG/DTA for the oxidation behavior characterization of vegetable and animal fats. Journal of Therma Analysis and Calorimetry, 110, 281-285.

Taracki, Z., Temiz, H., Aykut, U., \& Turhan, S. (2011). Influence of wild garlic on color, free fatty acids, and chemical and sensory properties of herby pickled cheese. International Journal of Food Properties, 14, 287-299.

Thermo Fischer Scientific Inc., USA, Software OMNIC 8.0.342. 